\title{
Influence of Sepitori on standard Setswana of its home language learners at three Tshwane townships
}

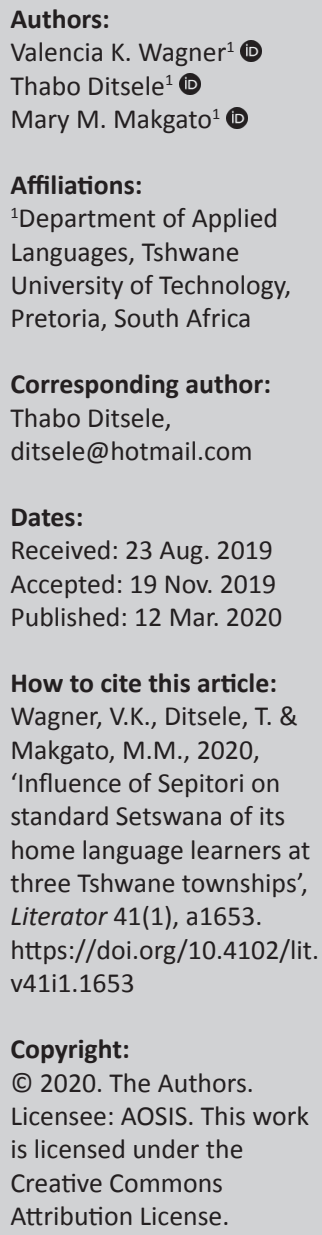

\begin{abstract}
This article established how a mixed language spoken as a lingua franca by black residents of Tshwane, known as Sepitori, influenced learners who studied Setswana as a home language at three high schools in GaRankuwa, Mabopane and Soshanguve; all these three townships are located north of Pretoria's central business district. Data were gathered from 90 learners (30 from each school) and six Setswana educators from the same schools. Learners wrote an essay in Setswana on an interesting and contemporary topic 'free education for all university students', while educators were interviewed individually. Data analysis showed that Sepitori significantly influenced the written output of learners. Some educators were adamant that it was unreasonable to wish away Sepitori in Setswana classrooms because learners and many educators (regardless of the subjects they taught) ordinarily spoke Sepitori at the three townships be it at school or at home.
\end{abstract}

Keywords: home language; standard variety; mixed language; Setswana; Sepitori.

\section{Introduction}

South Africa recognises its multilingual profile and has given official status to 11 languages (Constitution, Act No. 108 of 1996). In formal settings (e.g. education, media, workplace and business), standard varieties of these languages are used or preferred, while mixed languages are discouraged despite the fact that they are ordinarily spoken by many South Africans. Children born to families that speak mixed languages naturally pick them up and continue to speak them until they go to school where they are exposed to standard varieties. Calteaux (1996:150) notes that children who grow up in townships often learn colloquial varieties before acquiring a 'standard language', leading to various problems in the teaching of the 'standard language' in schools. Yiakoumetti (2007:53) submits that while even speakers who have access to standard varieties have instances of confusion (e.g. between formal and informal uses of language), speakers of mixed languages have many more instances of these differences to remember and are therefore presented with many more opportunities for error.

Ditsele and Mann (2014:163) note that the schooling system assumes that learners start grade 1 as home language (HL) speakers of standard varieties, when in fact they are not. As such, the schooling system uses teaching methods designed for speakers of standard varieties and that leads to a collision course between what these learners ordinarily speak on a daily basis (mixed languages) and what they learn at school (standard varieties). Furthermore, Webb (2010:160) submits that mainstream society projects standard varieties as the only correct and proper way of speaking and mixed languages as incorrect and improper.

This article seeks to determine how learners who ordinarily speak Sepitori (a mixed language spoken in Tshwane) are influenced by the variety as Setswana HL learners, years after entering the schooling system. As such, the following two research questions are posed:

1. Does Sepitori influence learners' written output of standard Setswana significantly or insignificantly?

2. What is Setswana educators' assessment on the influence that Sepitori has on standard Setswana?

\section{'Mother tongue' versus 'home language'}

According to the Department of Basic Education (2010:3), 'mother tongue' refers to the language that a learner has acquired in his or her early years and which has normally become his or her natural instrument of thought and communication, while ' $\mathrm{HL}$ ' refers to the language that is spoken most frequently at home by a learner. Ditsele and Mann (2014:162) note that in the 
South African school context, 'mother tongue' refers to standard varieties of 11 official languages. With regard to 'language learning areas', the Department of Basic Education (2010:3) refers to the standard varieties of these languages as ' $\mathrm{HL}^{\prime}$ and not 'mother tongues'. Thus, for all intents and purposes, the department indirectly equates 'mother tongue' to 'HL'.

Be that as it may, Webb, Lafon and Pare (2010:288) argue that South African sociolinguists prefer to use the term 'primary language' or ' $\mathrm{HL}$ ' to 'mother tongue' because the latter is problematical in the sense that it is often difficult to determine a person's 'mother tongue' as children in linguistically mixed homes and in similarly mixed communities spontaneously acquire different languages at the same time. We concur with Webb et al. (2010), and thus we prefer to use 'HL'.

\section{Language practice at research sites}

GaRankuwa, Mabopane and Soshanguve are located north of Pretoria's central business district in Tshwane. They are inhabited by black Africans with different cultural and linguistic backgrounds. According to Census 2011, Soshanguve ${ }^{1}$ is more diverse as it does not have a majority group of HL speakers, while GaRankuwa ${ }^{2}$ and Mabopane are populated by a majority of Setswana HL speakers.

It is important to note that Statistics South Africa, a government department responsible for official national censuses, asks citizens to identify one HL, and they can only choose from languages with official status. Álvarez-Mosquera, Bornman and Ditsele (2018:453) submit that linguistic and ethnic identities are still commonly defined according to languages with official status and that there is little recognition or acknowledgement of the reality that there are many citizens who have multiple linguistic identities or that mixed languages may be their HLs.

On 'ethnic identities', Bornman, Álvarez-Mosquera and Seti (2018) state:

[T]he majority of participants identified themselves in terms of an ethnic group. Many furthermore voiced pride in their ethnic and cultural identities, which were directly linked to ethnic languages and cultures. (p. 32)

Álvarez-Mosquera et al. (2018:453) note that citizens may only tick one of the 11 official languages when filling out official forms. So, in Tshwane, people whose strongest language is Sepitori would be forced to tick Setswana, Northern Sotho, Xitsonga and so on even when they lack HL speaker competence in these languages.

1.HL speakers in Soshanguve (first three): Northern Sotho (28\%), Setswana (17\%) and Xitsonga $(15 \%)$

2.HL speakers in GaRankuwa (first three): Setswana (69\%), Northern Sotho (8\%) and Xitsonga $(4 \%)$.

3. HL speakers in Mabopane (first three): Setswana (59\%), Northern Sotho (10\%) and Xitsonga ( $9 \%)$.
As such, it could be argued that citizens provide Statistics South Africa with their heritage languages (i.e. those associated with their ethnic identities which follow paternal lineage) as opposed to languages which people are strongest in, which may be mixed languages. In turn, Statistics South Africa presents, in censuses, citizens' heritage languages as their HLs. In the case of these three townships, residents ordinarily communicate in Sepitori, a mixed language, which, Ditsele (2014:220) argues, has had many generations of HL speakers as it developed soon after Pretoria was established by white people in 1855; these white people were Dutch speakers known as the Voortrekkers.

Schuring (1985:x) states that Sepitori represents basically the once-dominant Sekgatla dialect of Setswana spoken in Hammanskraal (a region north of Pretoria), with additions mainly from Northern Sotho (also known as Sepedi), Afrikaans and English.

Other than the presence of Setswana, Northern Sotho, Afrikaans and English in the linguistic composition of Sepitori, Malimabe (1990:10) suggests that the variety has a few lexical items from Southern Sotho, while Webb et al. (2010:281) add that it has elements of Nguni languages. As far as we are aware, no study has picked up the presence of Xitsonga and Tshivenda in the linguistic composition of Sepitori. Interestingly, according to Census 2011, Xitsonga has the third highest percentages of HL speakers in GaRankuwa, Mabopane and Soshanguve behind Setswana and Northern Sotho.

Bornman et al. (2018:30) submit that Sepitori has not only become the lingua franca in black residential areas but also serves as a marker of urbanisation and being 'city-wise'. People who migrate to this metropolitan area adopt it to distance themselves from their rural backgrounds. Even speakers living outside the municipal borders try to learn and speak Sepitori, seeking not only to add it to their linguistic repertoires but also to gain its concomitant positive social features such as urbanity, street wisdom, social recognition and/or 'coolness'.

Ditsele and Mann (2014:160) submit that Sepitori is neither written nor formal and that there can be no doubt that it developed out of contact between HL speakers of two Sotho-Tswana languages, namely, Setswana and Northern Sotho:

$[W]$ hile vocabulary from other languages is present in Sepitori (Malimabe 1990; Webb et al. 2010), such vocabulary is so negligible that it cannot be equated with that of Setswana and Northern Sotho. (Álvarez-Mosquera et al. 2018:453)

This is unsurprising, considering Census 2011 percentages presented earlier, which show that Setswana and Northern Sotho are by far the dominant HLs at the three research sites, GaRankuwa, Mabopane and Soshanguve. 


\section{Methodology}

The study used a mixed method approach, that is, Sepitori terms drawn from learners were counted (quantitative approach) and open-ended interview questions were used to gather data from educators (qualitative approach).

Data were gathered from 90 grade 9-11 learners at three high schools in GaRankuwa, Mabopane and Soshanguve. Three high schools (one from each of the three townships) were purposefully selected because they offered Setswana as an HL from grade 8 to grade 12. They were coded as follows: School A from GaRankuwa, School B from Mabopane and School C from Soshanguve.

To obtain data from learners, they were asked to write an essay in Setswana, which was two pages long on this interesting topic:

'Tsela eo nka tlamelang ka thuto ya mahala go baithuti bothe ba diyunibesithi, fa nkabo ke le Moporesitente.' ([loosely translated as:

'How I would provide free education for all university students, if I were the President.' (authors own translation)]

Face-to-face interviews were held with educators wherein eight semi-structured questions were put to them.

Ethical clearance was issued by Tshwane University of Technology's Research Ethics Committee on 18 November 2016, with ethical clearance number FCRE/APL/STD/ 2016/07. The next permission was granted by the Gauteng Department of Education and subsequently by the district and school management.

'Information letter and informed consent forms' were given to all grades 8-11 learners so as to take them home and get their parents or guardians to give consent. Learners were asked to sign and assent only after their parents or guardians had signed because the learners were all below the legal consenting age of 18 years. Grade 12 learners were not considered for the study because many schools are reluctant to release them as research participants because of their tight schedule. The first 30 learners (at each school) who returned duly signed forms were selected as participants.

\begin{tabular}{|c|c|c|c|c|}
\hline \multirow[t]{2}{*}{ Sex } & \multicolumn{2}{|c|}{ Learners } & \multicolumn{2}{|c|}{ Educators } \\
\hline & Number & $\%$ & Number & $\%$ \\
\hline Females & 52 & 57.8 & 4 & 66.7 \\
\hline Males & 38 & 42.2 & 2 & 33.3 \\
\hline Total & 90 & 100 & 6 & 100 \\
\hline
\end{tabular}

To seek answers to research Question 2, educators who taught Setswana at the three high schools were approached to participate in the study. Six of them (i.e. two from School A, three from School B and one from School C) agreed to participate in the study, and duly signed 'information letter and informed consent forms'. The study's sample population was 96 participants, that is, 90 learners and 6 educators. Table 1 shows their split according to 'sex'.

When it comes to educators, more details were obtained from them regarding their: (1) location of nurture, (2) proficiency in Sepitori and (3) highest qualification (see Table 2).

\section{Findings and discussions Analysis of learners' data}

Each of the 90 essays was read to identify Sepitori terms (including clauses and phrases) and to establish the languages from which such terms were drawn. Sepitori mainly draws its lexical items from Setswana and Northern Sotho, as it is a mixed language which developed from contact between these two languages, as such a hard line cannot be drawn between Sepitori's lexical items and those of Setswana and Northern Sotho. Like Setswana and Northern Sotho, Sepitori also comprises adoptives mainly drawn from English and Afrikaans. Tables 3-5 show the source languages of lexical items which have settled in Sepitori.

\section{Sepitori terms}

An overwhelming majority of learners (81.1\% or 73 out of 90$)$ wrote Sepitori terms in their essays albeit to varying degrees. This means that a small minority $(18.9 \%$ or 17 out of 90$)$ did not write any Sepitori terms. Of the 17 learners who did not write any Sepitori in their essays, five were from School A (GaRankuwa), nine were from School B (Mabopane) and three were from School C (Soshanguve). Based on the percentage distribution of Setswana HL speakers at GaRankuwa (69\%), Mabopane (59\%) and Soshanguve (17\%), one would have expected that Soshanguve would have had the highest number of learners who did not write any Sepitori in their essays, followed by Mabopane and GaRankuwa, but that was not the case as Soshanguve had the lowest number of learners (3), followed by GaRankuwa (5) and Mabopane (9).

Table 3 presents 10 Sepitori terms with the highest frequencies across the three schools.

High-frequency Sepitori terms, which are not acceptable in the formal writing of Setswana, were drawn from Northern

TABLE 2: Educators' split according to three more variables.

\begin{tabular}{|c|c|c|c|c|}
\hline Number & Sex & Location of nurture & Proficiency in Sepitori & Highest qualification \\
\hline 1 & Female & Grew up in Mahikeng, North West; moved to Tshwane as an adult & Weak & Bachelor's degree in Education (Setswana) \\
\hline 2 & Male & Lived in GaRankuwa all his life & Strong & Teacher's diploma (Setswana) \\
\hline 3 & Female & Grew up in Dipetlelwane, North West; moved to Tshwane as an adult & Weak & Postgraduate diploma in Education (Setswana) \\
\hline 4 & Female & Lived in Mabopane all her life & Strong & Bachelor's degree in Education (Setswana) \\
\hline 5 & Male & Moved to Mabopane in his early teens & Strong & Honours degree (Setswana) \\
\hline 6 & Female & Moved to Mabopane in her late teens & Weak & Teacher's diploma (Setswana) \\
\hline
\end{tabular}


TABLE 3: High-frequency Sepitori terms.

\begin{tabular}{|c|c|c|c|c|c|}
\hline Number & Sepitori terms & Source languages & Frequencies & Setswana equivalents & English equivalents \\
\hline 1 & batswadi & Northern Sotho and Southern Sotho & 30 & batsadi & parents \\
\hline 2 & taba & Northern Sotho and Southern Sotho & 16 & kgang/morero & matter/issue \\
\hline 3 & bolela/boledisana & Northern Sotho & 11 & bua/buisana & to speak/to speak to one another \\
\hline 4 & namella/namelletsa & Northern Sotho & 10 & tlhatloga/tlhatlosa & to go up/to increase \\
\hline 5 & sebetsa/mosebetsi & Southern Sotho & 9 & dira/tiro & to work/employment \\
\hline 6 & botsa & Northern Sotho & 9 & bolelela & to tell/to inform \\
\hline 7 & tseya & Northern Sotho & 8 & tsaya & to take \\
\hline 8 & nyaka & Northern Sotho & 8 & batla & to want \\
\hline 9 & tokelo & Northern Sotho and Southern Sotho & 6 & tshwanelo & right \\
\hline 10 & thaba & Northern Sotho and Southern Sotho & 6 & itumela & to be happy \\
\hline
\end{tabular}

Note: Eight Sepitori clauses and phrases presented in Table 4 give context to individual Sepitori terms, some of which were presented in Table 3. (Sepitori and Setswana equivalents are written in italics.)

TABLE 4: Sepitori clauses and phrases.

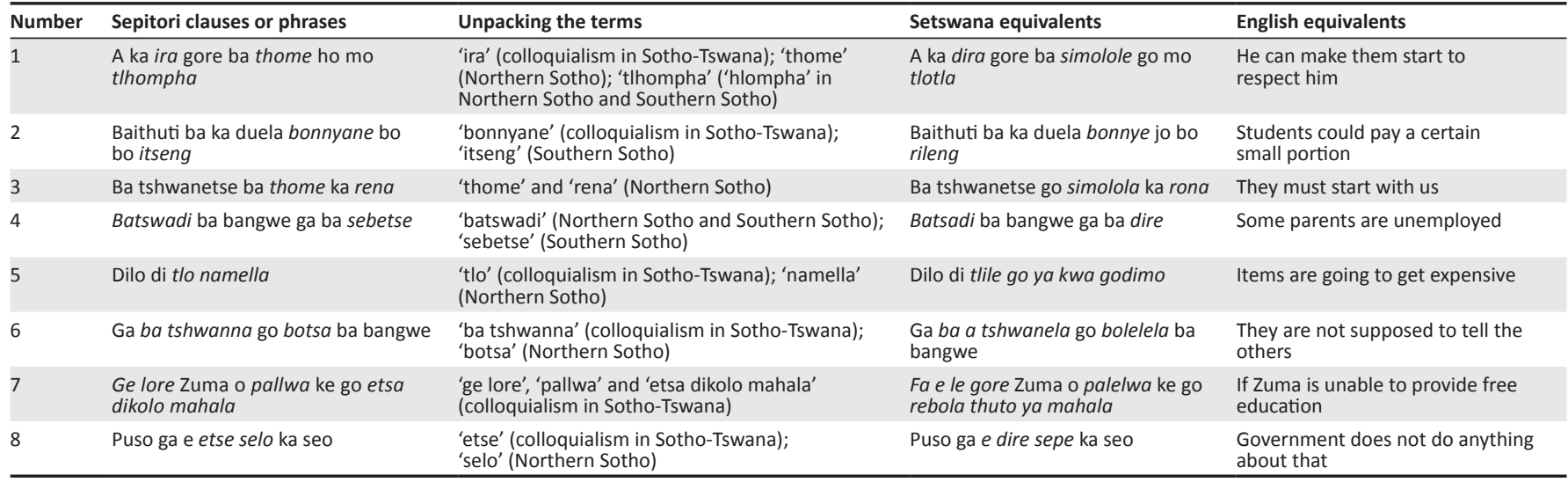

Sotho and Southern Sotho. This came as no surprise because as Matubatuba (2002:253) notes, Northern Sotho and Southern Sotho are mutually intelligible with Setswana. There were instances where learners used Sepitori terms (e.g. nyaka) in one paragraph and standard Setswana ones (e.g. batla) in another paragraph. This linguistic repertoire demonstrates that they have access to Sepitori and Setswana terms which are synonymous, but presume that they are both acceptable in the formal writing of Setswana.

In her study on learners who studied Northern Sotho as an HL in Soshanguve, Nkosi (2008) also found that learners could not separate Sepitori terms from Northern Sotho ones as they presumed that they were acceptable in the formal writing of Northern Sotho. As a solution to this challenge, Ditsele (2014:224) suggested that Setswana and Northern Sotho terms which are synonymous and considered unacceptable in the formal writing in the respective languages should be accepted by society as standard regional varieties of the languages. For example, it should be acceptable to use 'dumelang' ('hello' in Setswana and Southern Sotho) and 'tsamaya' ('to go' in Setswana and Southern Sotho) when speaking or writing standard Northern Sotho in Tshwane, much as it should be permissible to use 'nyaka' ('to want' in Northern Sotho) and 'betha' ('to hit' in Northern Sotho) when speaking or writing standard Setswana in Tshwane.

Learners did not write any terms drawn from Xitsonga and Tshivenda. Learners did not write any terms drawn from Nguni languages, which was surprising because Webb et al.
(2010:281) suggested that the terminology of Nguni languages was making inroads into Sepitori. Perhaps in fairness to them, their data were gathered at locations whose linguistic compositions were different to those of GaRankuwa, Mabopane and Soshanguve.

Besides the high frequency of Sepitori terms which were drawn from Northern Sotho and Southern Sotho, learners wrote adoptives attributed to Afrikaans and English (see Table 5 for a few of them). According to Madiba (1994:4), 'adoptives' are 'those foreign linguistic forms that have received formal acceptance and reflect widespread use in the recipient language'.

\section{Trends emerging from learners' data}

Although a majority of the learners who participated in the study were female, a majority of Sepitori terms were written by male participants. This finding is supported by Xia (2013) who argues that females pay more attention to using standard language than men do, so they are stricter with the rules of the use of language.

A closer look at the data suggested that the Setswana written by learners at School C (Soshanguve) had a higher frequency of Sepitori terms, followed by learners at School A (GaRankuwa). Learners at School B (Mabopane) had the lowest frequency of the three. This finding is not surprising because Soshanguve has a far more multi-ethnic profile relative to GaRankuwa and Mabopane which are predominantly Setswana. 
TABLE 5: Sepitori adoptives.

\begin{tabular}{lllll}
\hline $\begin{array}{l}\text { Sepitori } \\
\text { terms }\end{array}$ & $\begin{array}{l}\text { Original } \\
\text { terms }\end{array}$ & $\begin{array}{l}\text { Languages } \\
\text { adopted from }\end{array}$ & Setswana terms & English equivalents \\
\hline afota & afford & English & bokgoni jwa go duela & afford \\
bereka & werk & Afrikaans & dira & work \\
dijara & jare & Afrikaans & dingwaga & years \\
dipokoto & pockets & English & dikgetse & pockets \\
flopa & flop & English & dira phoso & make a mistake (flop) \\
kereya & kry & Afrikaans & fitlhela & find \\
patela & betaal & Afrikaans & duela & pay \\
polane & plan & Afrikaans and English & leano & plan \\
safara & suffer & English & sotlega & suffer \\
tura & duur & Afrikaans & tlhwatlhwa godimo & expensive \\
\hline
\end{tabular}

\section{Analysis of educators' data}

Six educators from the three schools were interviewed individually in Setswana by the first author (see Table 2 for their profiles). The interview schedule comprised eight questions, which were open-ended and allowed the educators to elaborate more where it was necessary. The overall interview responses from the educators are presented below.

\section{Question 1: What language(s) do you speak at home?}

Two out of the six educators stated that at home they spoke a more standardised version of Setswana; three said that they spoke Sepitori; and one said she spoke both Setswana and Sepitori. This question was meant to establish the educators' linguistic background, with a view to establish how far the languages they spoke at home were from the language they taught, Setswana. All of them we deemed to have a good command of Setswana, including Educator no. 5 (see Table 2), who said that his HL was Northern Sotho; this seems to be more about his heritage than his language practice experience.

\section{Question 2: Do you speak Sepitori?}

All but one educator stated that they spoke Sepitori. Educator no. 1 was the only one who stated that she did not and said that she still spoke a more standardised version of Setswana, which she grew up speaking in Mahikeng, North West. Because of the prevalence of Sepitori in Tshwane, it was important to establish the educators' familiarity with this language, and all but one were found to have solid knowledge of the language.

Question 3: Under which circumstances do you speak Sepitori to your learners?

Educators indicated that they communicated with their learners in Sepitori inside and outside the classroom. Educator no. 2 noted that there were instances when learners did not understand the point being made in standard Setswana, a situation that necessitated that he spoke Sepitori for clarity. He remarked:

'Sometimes, the learners do not understand certain words in Setswana; as a result, I end up switching to Sepitori for me to transfer the necessary knowledge to the learners successfully.' (Educator no 2, male, strong Sepitori proficiency)

Outside the classroom, some educators communicated with learners in Sepitori because it was a natural thing to do. This was also influenced by the fact that many educators (i.e. those who taught other subjects) at these schools spoke Sepitori as an HL.

On this note, Webb et al. (2010:281) argue that the inadequate development of Bantu $\mathrm{u}^{4}$ languages as fully fledged standard languages means that when HLs are used in the classrooms, it is not the standard varieties that are used, but the urban vernaculars such as Sepitori (which they referred to as 'Pretoria Sotho'), Tsotsitaal, Iscamtho and Gauteng Zulu, which Ditsele (2017:1) refers to as 'Jozi Zulu' because of its concentration in greater Johannesburg and as opposed to other areas of the province such as Tshwane.

Furthermore, Calteaux (1996:66) states that mixed languages (which she refers to as Black Urban Varieties) are found in most townships and are mainly used in informal situations including the home and at the workplace under informal situations. She also maintains that the use of Sepitori is spreading to formal domains such as classrooms, such as was the case at Tembisa schools where evidence showed that some educators used mixed languages to explain the content of the subject to learners when they were unable to understand it in English.

Question 4: When your learners do not understand you in class, do you speak Sepitori so they understand you better?

Educator no. 1 indicated that she did not speak Sepitori under any circumstances in the classroom because she believed that there were always other words that she could use to explain better in Setswana. She remarked:

'I am not a Sepitori speaker in any case, so I might not even know what the word means in Sepitori; I would much rather try and find other ways of explaining in Setswana.' (Educator no 1, female, weak Sepitori proficiency)

Other educators admitted to speaking Sepitori to help their learners understand certain Setswana concepts better.

Olcay (2005:6) supports classroom code-switching ${ }^{5}$ when he states that in a language classroom, code switching is not always a blockage or deficiency in learning a language, but may be considered as a useful strategy in classroom interaction, if the aim is to make meaning clear and to transfer the knowledge to the students in an efficient way. Ncoko, Osman and Corkcroft (2000:239) articulate the opinion that code-switching as a teaching strategy can be effective for both language and content acquisition, as it possesses several communicative functions in the classroom, namely, translation, clarification, checking comprehension, giving instructions and procedures, as well as acting as a 'we-code'.

4.Ditsele (2014:226) notes: "In most literature in South Africa, the term "African languages" is used to refer to the "Southern Bantu languages" spoken in the country. Some researchers such as Dyers (1999) prefer to use the term "Black South African languages"'.

5.According to Myers-Scotton (1993), 'code-switching' is the mixing of different codes . According to Myers-Scotton (1993), 'code-switching is the mixing of different codes
by speakers in the same conversation. The switch may take place at any level of by speakers in the same conversation. The switch may take place at any level of
language differentiation (i.e. languages, dialects and styles/registers) and can involve units from the morpheme to the sentence. 
Calteaux (1996:148), on the contrary, believes that although the use of a mixed language to explain issues in content subject lessons might still be tolerable, such language use during standard language lessons is a cause for serious concern because that has the potential to impede the learning of a standard language.

Question 5: How often do your learners write Sepitori words in their work? Do you penalise them for using Sepitori?

All the educators mentioned that they always came across Sepitori terms when marking their learners' written work, especially essays. According to them, the following was their percentage splits of their learners' use of Sepitori in their written work: (1) OFTEN $=80 \%$, (2) SELDOM $=20 \%$ and (3) NEVER $=0 \%$. This statistical breakdown demonstrates that Sepitori was present in a lot of Setswana HL learners.

With regard to the second part of the question, Educator no. 1 remarked that she penalised her learners for writing Sepitori terms in their written work; she said that she reduced their marks to ensure that they did not repeat the same mistakes. Of those who did not penalise them, Educator no. 4 stated:

'I do not penalise them; I only show and highlight the correct words in Setswana.' (Educator no. 4, female, strong Sepitori proficiency)

Tegegne (2015:267) points out that many materials used in classrooms are prepared in a standard variety and that learners who speak the standard variety are familiar with sounds and vocabulary of the standard variety. So, it is easier for standard variety learners to read and understand than for those who speak the mixed language. He is also of the opinion that the negative impression and the treatment of the mixed languages in school can affect students' learning.

Question 6: Should the use of Sepitori in school be minimised so as to reduce its influence on Setswana?

Four out of the six educators believed that the use of Sepitori should be minimised in schools to reduce its influence on Setswana. The main reasons they provided were as follows:

'Yes, because language and culture are intertwined. If we lose our language, we lose our culture. Therefore, the only way to hold on to our Setswana culture is if we hold on to our language. Setswana is a beautiful language and we cannot let it die.' (Educator no. 1, female, weak Sepitori proficiency).

'I think that we need to discourage both the learners and educators from speaking Sepitori in Setswana classrooms because it negatively affects the learners' knowledge of standard Setswana. It is our responsibility as educators to motivate these learners to value Setswana as a language.' (Educator no. 2, male, strong Sepitori proficiency).

'Absolutely, because using Sepitori does not enhance Setswana and causes Setswana to dwindle down.' (Educator no. 3, female, weak Sepitori proficiency)

'Yes, because if we do not do that, these children will never understand the difference between Sepitori and standard Setswana.' (Educator no. 6, female, weak Sepitori proficiency).

The remaining two educators felt that trying to minimise Sepitori in the classroom would be equivalent to fighting a losing battle. Their reasons were as follows:
'It is impossible for these learners not to use Sepitori in the classroom because it is their everyday language. Most of them do not do it deliberately; they write Sepitori because they really do not know the correct form.' (Educator no. 4, female, strong Sepitori proficiency)

'These children speak Sepitori all the time. The only time they think or speak standard Setswana is during the Setswana period. Whether we like it or not, Sepitori will always have an influence on Setswana.' (Educator no. 5, male, strong Sepitori proficiency)

Question 7: What would you say if someone suggested that Sepitori words should be adopted into Setswana so that leaners' performance in class could improve? Would you support this or not?

Only two educators were in support of this statement, namely, Educator no. 2 and Educator no. 4.

'Yes, I would support this because most people who live in this township are not Batswana. There are a lot of people from different ethnic groups living here, which means that many of these children are not Batswana. The only reason why they end up learning Setswana in school is because of the environment that they live in. This will help a lot in reducing the failure rate of these learners.' (Educator no. 2, male, strong Sepitori proficiency)

'I would support this because it is very difficult to stop these children from speaking Sepitori in class. Incorporating the two languages will make them even keener to learn Setswana as their HL and eventually improve their performance in the classroom.' (Educator no. 4, female, strong Sepitori proficiency)

Question 8: Do you think that Sepitori has a potential of being developed into a standard language for the residents of Tshwane?

Five out of six educators believed that Sepitori had the potential of being developed into a standard language. One of them mentioned that during the marking of final-year grade 12 examination papers at a marking centre, an examiner (who was from Mabopane) in a senior position had instructed them to not penalise learners who wrote Sepitori in the standard Setswana work, but credit them instead; that approach from that senior position made her believe that Sepitori could one day be recognised as one of the standard languages.

\section{Conclusion}

The analysis of the first set of data (from learners) showed that Sepitori had a significant influence on the written output of learners who studied standard Setswana at three selected townships in Tshwane (viz. GaRankuwa, Mabopane and Soshanguve) albeit at varying levels. It is thus concluded that Sepitori influenced learners' written output of standard Setswana significantly, which provides an answer to the first research question.

With regard to the second research question, the analysis of the second set of data (from educators) showed that educators' assessment was that Sepitori had a huge influence on the written output of their learners, and they were unequivocal in that assessment. They thought that it was unreasonable to wish away Sepitori in Setswana classrooms because learners and many educators (regardless of subjects they taught) ordinarily spoke Sepitori at the three townships be it at school or at home. 
The finding confirms the findings by Malimabe (1990) and Nkosi (2008) who both found that Sepitori influenced the standard varieties of Setswana and Northern Sotho, respectively. The finding perhaps adds a voice to Webb (2010) who is of the view that society needs to recognise and accept the fact that mixed languages will always influence standard varieties in classroom situations.

Sigcau (1998:90) submits that students who make use of nonstandard varieties are disadvantaged academically. It is the duty of language planners and subject advisors to change the attitude of educators about the non-standard varieties. Deumert (2005:31) states that it may be true that the concept of standard language which language planners generally work with (uniformity of linguistic form and structure; low levels of variation and the belief in linguistic purity and 'beauty') is no longer applicable in a postmodern world.

Hurst (2014) submits that societal attitudes towards mixed languages are changing and that there is a shift towards acknowledging their positive role in society. In this study, one educator remarked that a senior education official (an examiner) showed a positive attitude towards Sepitori.

Researchers such as Calteaux (1996) have conducted extensive research on the influence that mixed languages have on standard ones. Beyond this undisputed finding, more research needs to be conducted on how to take advantage of mixed languages and seek to empower standard ones; in other words, how Sepitori could be given space to grow and develop standard Setswana, as was suggested by Ditsele (2014).

\section{Acknowledgements}

The authors wish to express their sincere appreciation to the 96 participants (i.e. 90 learners and 6 educators) from three Tshwane high schools who participated in this study.

\section{Competing interests}

The authors have declared that no competing interest exists.

\section{Authors' contributions}

This article was written out of V.K.W.'s Master's research project under the supervision of T.D. and co-supervision of M.M.M.; V.K.W. drafted the article, while T.D. and M.M.M. revised and finalised it.

\section{Funding information}

This research received no specific grant from any funding agency in the public, commercial or not-for-profit sectors.

\section{Data availability statement}

Data sharing is not applicable to this article as no new data were created or analysed in the study.

\section{Disclaimer}

The views and opinions expressed in this article are those of the authors and do not necessarily reflect the official policy or position of any affiliated agency or the authors.

\section{References}

Álvarez-Mosquera, P., Bornman, E. \& Ditsele, T., 2018, 'Residents' perceptions on Sepitori, a mixed language spoken in greater Pretoria, South Africa', Sociolinguistic Studies 12(3-4), 439-459. https://doi.org/10.1558/sols.33643

Bornman, E., Álvarez-Mosquera, P. \& Seti, V., 2018, 'Language, urbanisation and identity: Youth Black residents from Pretoria in South Africa', Language Matters: Studies in the languages of Africa 49(1), 25-44. https://doi.org/10.1080/1022819 5.2018 .1440318

Calteaux, K., 1996, Standard and non-standard African language varieties in the urban areas of South Africa: Main report for the Stanon Research Programme, Human Sciences Research Council, Pretoria.

Census, 2011, Statistics South Africa, Pretoria, viewed 18 June 2019, from http:// www.statssa.gov.za/?page_id $=3839$.

Department of Basic Education, 2010, 'The status of the Language of Learning and Teaching (LOLT) in South African public schools: A quantitative overview', Department of Basic Education, Pretoria.

Deumert, A., 2005, 'The shape of the standard - Reflections on post-colonial standard languages, with special attention to South Africa', in V. Webb, A. Deumert \& B. Lepota (eds.), The standardisation of African languages in South Africa: Report on the workshop held at the University of Pretoria, PanSALB Occasional Papers, Pretoria, pp. 17-34.

Ditsele, T., 2014, 'Why not use Sepitori to enrich the vocabularies of Setswana and Sepedi?', Southern African Linguistics and Applied Language Studies 32(2), 215228. https://doi.org/10.2989/16073614.2014.992652

Ditsele, T., 2017, 'The promotion of Setswana through hip hop and motswakolistas', Journal of the Musical Arts in Africa 14(1-2), 1-14. https://doi.org/10.2989/1812 1004.2017.1410990

Ditsele, T. \& Mann, C.C., 2014, 'Language contact in African urban settings: The case of Sepitori in Tshwane', South African Journal of African Languages 34(2), 159-165. https://doi.org/10.1080/02572117.2014.997052

Dyers, C., 1999, 'Xhosa students' attitudes towards Black South African languages at the University of the Western Cape', South African Journal of African languages 19(2), 73-82. https://doi.org/10.1080/02572117.1999.10587384

Hurst, E., 2014, 'South African urban youth language research: The state of the nation', Paper read at the Sociolinguistics Symposium 20, 15-18 June, Jyväskylä, Finland, Unpublished.

Madiba, M.R., 1994, 'A linguistic survey of adoptives in Venda', Master's dissertation, University of South Africa, Pretoria.

Malimabe, R.M., 1990, 'The influence of non-standard varieties on the standard Setswana of high school pupils' Master's dissertation, Rand Afrikaans University, Johannesburg.

Matubatuba, E.N., 2002, 'The Sotho-Tswana language group and harmonisation', in K.K. Prah (ed.), Speaking in unison: The harmonisation and standardisation of Southern African languages, pp. 249-258, CASAS, Cape Town.

Myers-Scotton, C., 1993, Duelling languages: Grammatical structure in codeswitching, Oxford University Press, New York.

Ncoko, S.O.S., Osman, R. \& Cockcroft, K., 2000, 'Codeswitching among multilingua learners in primary schools in South Africa: An exploratory study', International Journal of Bilingual Education and Bilingualism 3(4), 225-241. https://doi.org/ 10.1080/13670050008667709

Nkosi, D.M., 2008, 'Language variation and change in a Soshanguve high school', Master's dissertation, University of South Africa, Pretoria.

Olcay, S., 2005, 'The functions of code-switching in ELT classrooms', TESL Journal 8(3), 320-324.

Republic of South Africa, 1996, The Constitution of the Republic of South Africa (Act 108 of 1996), Government Printers, Pretoria.

Schuring, G.K., 1985, 'Die omgangs-Sotho van die swart woongebiede van Pretoria', Doctoral thesis, University of South Africa, Pretoria.

Sigcau, N.E., 1998, 'Educational implications of non-standard varieties of Xhosa', Master's dissertation, University of Cape Town, Cape Town.

Tegegne, W., 2015, 'The use of dialects in education and its impacts on students' learning and achievements', Education Journal 4(5), 263-269. https://doi.org/ 10.11648/j.edu.20150405.22

Webb, V., 2010, 'The politics of standardising Bantu languages in South Africa', Language Matters: Studies in the Languages of Africa 41(2), 157-174. https://doi. org/10.1080/10228195.2010.500674

Webb, V., Lafon, M. \& Pare, P, 2010, 'Bantu languages in education in South Africa: An overview. Ongekho akekho! - The absentee owner', The Language Learning Journal 38(3), 273-292. https://doi.org/10.1080/09571730903208389

Xia, X., 2013, 'Gender differences in using language', Theory and practice in language studies 3(8), 1485-1489. https://doi.org/10.4304/tpls.3.8.1485-1489

Yiakoumetti, A., 2007, 'Choice of classroom language in bidialectal communities: to include or to exclude the dialect?', Cambridge Journal of Education 37(1), 51-66. https://doi.org/10.1080/03057640601179046 